\title{
TERRITÓRIO USADO, PANDEMIAS E AÇÕES (SOCIALMENTE) CONSEQUENTES
}

\author{
TERRITOIRE UTILISÉ, PANDÉMIES ET \\ ACTIONS (SOCIALEMENT) CONSÉQUENTES
}

Cláudio Jorge Moura de CASTILHO1

Artigo recebido em 18/07/2020, aceito em 09/12/2020, publicado em 28/12/2020.

\section{Palavras-chave: Comunidades de interesse social; Uso desigual e injusto do território; \\ Contradições; Recife.}

Keywords:

Territoires des pauvres; Utilisation inégale et injuste du territoire:

Contradictions;

Recife.

\section{RESUMO}

Apesar de não ser facilmente evidente, há uma forte relação entre território usado, pandemias e ações sociais historicamente contextualizadas, a qual também constitui assunto de fundamental relevância para o entendimento do mundo como uma totalidade complexa que se acha em permanente movimento. Delimitou-se como objetivo geral, a análise desta relação no contexto de uma sociedade de classes fortemente desigual e injusta como a brasileira, sujeita a impactos mais graves ocasionados por pandemias dentre as quais a da COVID-19. 0 materialismo histórico-dialético constituiu o método de abordagem escolhido para a operacionalização da análise, em função do seu caráter dinâmico e aberto. Como conclusões gerais, aponta-se que o fenômeno da COVID-19 manifesta-se de acordo com a natureza do uso do território, daí a necessidade de refletir sobre a natureza deste uso a fim de imaginar perspectivas mais justas de uso do território que sejam capazes de combater, no presente e no futuro, os impactos negativos dos fenômenos.

\section{RÉSUMÉ}

Malgré le fait qu'il ne s'agit pas d'une chose évidente, il y a un fort rapport entre territoire utilisé, pandémies et actions sociales lequel possède pertinence fondamentale à la compréhension du monde comme une totalité complexe qui se trouve dans un mouvement permanent de changement. L'objectif général a éte l'analyse de ces rapports dans un contexte d'une société de classes fortement inégale et injuste à l'exemple de la brésilienne, où l'on peut avoir des impacts plus graves provoqués par les pandémies parmi lesquelles celle de la COVID-19. Le matérialisme historique et dialectique a été l'approche méthodologique choisie pour la concrétisation de l'analyse, en fonction de son aspect très dynamique et ouvert. Quant aux principales conclusions, on a soutenu que le phénomène de la COVID-19 se manifèste d'après la nature du territoire utilisé, ce qui nous amène à réfléchir sur l'usage du territoire afin d'imaginer d'autres possibilités de combattre, dans le présent et à l'avenir, ses effets négatifs.

\footnotetext{
${ }^{1}$ Professor do Programa de Pós-graduação em Desenvolvimento e Meio Ambiente da Universidade Federal de Pernambuco E-mail: claudiocastilho44@gmail.com
} 


\section{INTRODUÇÃO}

A geografia, como acentuaram Santos et al. (2000), é um campo do conhecimento científico que estuda a sociedade pelo território usado pelos homens e pelas mulheres, no curso das suas respectivas histórias de vida no mundo. A opção pelo território usado como categoria de análise da sociedade permite-nos entender as consequências do fenômendo da expansão da COVID-19, na medida em que leva em conta o papel das desigualdades e injustiças socioterritoriais como rugosidades herdadas da natureza do processo de formação histórico-territorial do capitalismo no Brasil.

Segundo Santos \& Silveira (2001), não é apenas o território em si que interessa, mas, ao mesmo tempo, o território usado, ou seja, o uso que a sociedade fez/faz dos espaços de que se apropria, como suporte, meio e condição, para atender aos seus propósitos. O território compreende, segundo Santos (1997), o espaço como um conjunto indissociável, solidário e contraditório de sistemas de objetos e de ações que, formando uma totalidade complexa, acha-se em permanente processo de totalização, em algum sentido. Sentido este que se acha intrinsecamente atrelado à dinâmica das relações de forças que produzem o território e que, somente 0 acontecer histórico desta dinâmica pode apontá-lo.

Em uma sociedade de classes como a capitalista, geralmente, o território é usado, preponderantemente, para atender aos interesses das classes dominantes, a menos que as classes subalternizadas estejam organizadas e mobilizadas, a partir dos seus territórios de existência, para também fazerem valer os seus interesses, atrapalhando, assim, a lógica hegemônica, ou seja, impondo processos de resistência à referida lógica. Nesse sentido, o território constitui um mosaico fragmentado e, contraditoriamente, combinado dos interesses da coletividade social.

O conflito de classes, portanto, motor da história social do capitalismo, engendra uma estrutura territorial fragmentada e segregada, com graus sofríveis de articulação. Esta estrutura é, portanto, resultado e causa de uma série de desigualdades e injustiças socioterritoriais, cujos graus de variação dependem da natureza do processo da formação histórico-territorial. A reprodução no tempo-espaço de tais desigualdades e injustiças se torna mais grave quando o território é usado como recurso à reprodução permanente do modelo hegemônico. De acordo com Santos et. al. (2000, p. 12-13),

Para os atores hegemonicos o território usado é um recurso, garantia da realização de seus interesses particulares. [...] o rebatimento de suas ações conduz a uma constante de adaptação de seu uso com adição de uma materialidade funcional ao exercício das atividades exógenas ao lugar, aprofundando a divisão social e territorial do trabalho, mediante a seletividade dos investimentos econômicos que gera um uso corporativo do território. [...] Os distintos atores não possuem o mesmo poder de comando levando a uma multiplicação de ações, fruto do convívio com os atores hegemonizados. Dessa combinação temos o arranjo singular dos lugares. Os atores hegemonizados [subalternizados] têm o território como um abrigo, buscando constantemente se adptar ao meio geográfico local, ao mesmo tempo que 
recriam estratégias que garantam sua sobrevivência nos lugares. É neste jogo dialético que podemos recuperar a totalidade.

No curso do processo da formação histórico-territorial brasileira, as classes dominantes sempre usaram o território nacional para atender, preponderantemente, aos seus interesses patrimonialistas, privatistas e economicistas, submetendo, pelo consenso, as classes subalternizadas às formas mais exacerbadas e cruéis de exploração, visando garantir os seus privilégios. A concretização de tais interesses destruiu partes significativas da natureza e da cultura dos povos autóctones (Ribeiro, 2015; Castilho, Pontes \& Brandão, 2018), negando e massacrando cruelmente as diversas reações dos movimentos sociais (Ribeiro, 2015; Castilho, 2020), sem esconder seu ódio e medo com relação às classes que, através destes movimentos, ameaçam a manutenção dos privilégios.

As especificidades territoriais inerentes a cada lugar influem na dinâmica do acontecer histórico de qualquer fenômeno. Em outras palavras, apesar de acontecer simultaneamente em todos os territórios do espaço geográfico mundial, o fenômeno da COVID-19, por exemplo, atinge-os de maneira diferente segundo a natureza social de cada lugar. Ao mesmo tempo, as referidas especificidades influem nas formas locais de reação à manifestação e ao enfrentamento das consequências do referido fenômeno.

O objetivo geral do presente ensaio consiste na análise das relações entre a materialidade do espaço urbano do Recife como território usado e a pandemia da COVID-19, no contexto de uma sociedade de classes fortemente desigual e injusta como a brasileira, estimulando a reflexão acerca da possibilidade de ações socialmente consequentes, ou seja, aquelas que visam à promoção de uma habitabilidade humanamente sustentável.

O materialismo histórico-dialético constitui a perspectiva metodológica pela qual se optou para a realização da abordagem do tema ora delimitado. Isto porque o espaço, compreendido como território usado, é, ao mesmo tempo, resultado e processo contínuo das inter-relações contraditórias e conflituosas de classes, no âmbito do permanente acontecer histórico do capitalismo. Destarte, a pandemia da COVID-19 faz-se presente em um espaço urbano que, formado historicamente no âmbito de um mosaico territorial fortemente desigual e injusto, contribui para agravar, principalmente, a situação das classes sociais subalternizadas.

\section{METODO}

Visando à operacionalização do método de abordagem proposto, utilizamo-nos dos seguintes procedimentos metodológicos: revisão não exaustiva da literatura acerca das principais variáveis desta reflexão (espaço urbano, pandemia e ações socialmente consequentes); escuta de homens e mulheres que, 
pertencentes às classes sociais subalternizadas, mais sofrem com a propagação da pandemia da COVID-19; e utilização de mapas do fenômeno abordado com a finalidade de esclarecer a discussão estabelecida.

A despeito de haver um enorme acervo teórico sobre as variáveis supracitadas, o procedimento de revisão da literatura optou, apenas, pelos mais pertinentes para a realização da discussão. Ademais, em se considerando, na análise, um fenômeno que está em seu pleno acontecer, o da COVID-19, evitou-se correr 0 risco do citacionismo exacerbado e infrutífero que poderia desviar a atenção do foco da discussão.

No que diz respeito à escuta das pessoas, este procedimento foi realizado, através de entrevistas informais, em locais que retratam de maneira patente o sofrimento das pessoas. Priorizando as pessoas que moram em Comunidades de Interesse Social (CIS), as entrevistas foram feitas onde elas estavam buscando sua sobrevivência, ou seja, em: filas de agências bancárias que pagam auxílios emergenciais aos trabalhadores e às trabalhadoras atingidos/as pela pandemia; terminais de ônibus; e ruas comerciais da Área Central do Recife. Ressalta-se que, para proteger os/as respondentes, como nos alertara Lacoste (2019), buscou-se omitir qualquer informação que pudesse revelar as suas respectivas identidades.

Acrescenta-se que o pesquisador usou máscara facial e manteve o distanciamento necessário de, no mínimo, um metro e meio dos/das respondentes, respeitando as recomendações dos governos estadual e municipal as quais, por seu turno, estavam de acordo com as orientações da Organização Mundial da Saúde (OMS).

Para a realização das entrevistas, escolheu-se, aleatoriamente, 20 pessoas que estavam em filas da Caixa Econômica Federal (CEF) a fim de receberem o auxílio disponibilizado pelo Governo Federal; 20 pessoas que estavam em filas de ônibus no interior de terminais integrados de passageiros para ir aos seus postos de trabalho; e 15 pessoas que se achavam em espaços comerciais da Área Central histórica do Recife na busca de algum ganho a fim de comprarem alimentos para seus familiares, somando um total de 55 entrevistados/as. A escolha desses lugares para a realização das entrevistas deveu-se, sobretudo, ao fato de serem áreas frequentadas pelas pessoas que não reuniam, à época, as condições de manterem-se em suas casas durante a pandemia, apesar de terem medo de serem infectadas pela COVID-19.

Por último, mas não de menor relevância para a realização do presente ensaio, utilizou-se de mapas que representam algumas das principais variáveis inerentes à problemática ora abordada, com vistas a, notadamente, tornar mais evidentes os seus principais sentidos e, ao mesmo tempo, vislumbrar perspectivas concretas visando à sua superação.

\section{RESULTADOS E DISCUSSÃO}

Não constituindo um epifenômeno, o território não constitui somente o espaço onde as ações humanas acontecem, mas, ao mesmo tempo, é uma instância material produzida e usada como meio e condição para 
atender aos interesses da sociedade que necessita apropriar-se dele para existir. Em se tratando de uma sociedade de classes, os interesses predominantes são aqueles que representam os propósitos das classes dominantes, impondo-se sobre os das classes subalternizadas.

Em países como o Brasil, a permanência, no tempo-espaço, das desigualdades e injustiças socioterritoriais inerentes à racionalidade técnico-instrumental capitalista, aproveitando-se de formas culturais não-capitalistas de ser e pensar, produz territórios insustentáveis à realização plena da vida humana, deixando sempre as classes subalternizadas mais vulneráveis aos efeitos de quaisquer tragédias a exemplo das que se caracterizam como pandemias; o que, por seu lado, dificulta a realização de ações capazes de enfrentá-las e combatê-las visando ao estabelecimento do abrigo e, portanto, da proteção social.

\subsection{Recife: um espaço socioterritorialmente fragmentado, desigual e injusto}

Importante centro urbano da região Nordeste do Brasil, Recife, segundo o BNB (2019), compreendia, em 2018, um espaço com cerca de 218 km²; possuía população total de 1.637 .834 habitantes; e densidade demográfica de 7.498,0 habitantes por km². Esta centralidade constitui o núcleo da Região Metropolitana do Recife (RMR) cuja população total chegou, em 2018, de acordo com FNEM (2019), a 4.054.866 habitantes, considerando o município de Goiana.

De acordo com Lab Moradia no Centro (2018), com base no Atlas das Infraestruturas Públicas em Comunidades de Interesse Social (CIS), realizado pela Autarquia de Saneamento do Recife (Sanear), entre 2014 e 2016, cerca de 53\% da população total do Recife moravam em CIS, cobrindo 35\% da área urbanizada da cidade. Muitas CIS achavam-se localizadas no interior do perímetro de 74 Zonas Especiais de Interesse Social (ZEIS) e 304 achavam-se fora das ZEIS, evidenciando o significativo número de territórios cujos moradores enfrentam, há décadas, dificuldades para obterem a regularização fundiária e urbanística garantida pela legislação da ZEIS.

Essa realidade é fruto de um processo de formação histórico-geográfica que engendrou paisagens urbanas significativamente desiguais e injustas, constituindo um mosaico fragmentado e, contraditoriamente, articulado de territórios sob a lógica dos interesses inerentes a uma sociedade de classes muito perversa. Em Recife, portanto, esta articulação está distante da perspectiva de propiciar relações plenas de proximidade entre as classes sociais existentes.

Até se percebe aproximação física entre elas, mas a aproximação social é sofrível. A fragmentação histórico-geográfica foi representada por Castro (1954), Freyre (1981) e Melo (1978), dentre outros autores clássicos, pela visível presença de desigualdade entre os habitantes de "terras firmes" e "terras alagadas", estas situadas em "áreas de manguezais": as primeiras de grande valor justificando sua maximização em termos de construção dos sobrados, residências das classes dominantes; e as segundas constituíam espaços 
economicamente desvalorizados em função da dificuldade, sobretudo nos tempos iniciais da formação territorial da cidade, para construir, razão pela qual estes se tornaram espaços ocupados pelas classes subalternizadas, portanto onde elas levantavam seus mocambos.

Se, por exemplo, para Melo (1978, p. 68), "[...] não longe deles [dos espaços de terra firme], ou até beirando-os, existiam as áreas dos manguezais...”, também para Bitoun (1996, p. 44-45),

[...] no Recife, nenhuma concentração de população de renda alta e média está localizada a mais de $1.200 \mathrm{~m}$ de um assentamento popular gerando práticas sociais de vizinhança entre setores sociais que convivem no mesmo bairro. No entanto, existem [...] bairros exclusivamente ocupados por populações de baixa renda, em localizações periféricas dificultando 0 acesso ao mercado de trabalho e tornando ainda mais remotas as perspectivas de mobilidade social.

A constatação da referida proximidade, assim, não significa que tenha existido, consequentemente, relações de convivência social entre as classes sociais justapostas no espaço urbano, o que se deve, ao mesmo tempo, à permanência da dimensão racista e preconceituosa das classes dominantes com relação às subalternizadas, fazendo com que estas últimas sempre tenham sido mantidas afastadas das anteriores. Por outro lado, nota-se que, após a realização dos aterros das áreas de manguezais pelas próprias classes subalternizadas, valorizando-as, os interesses das classes dominantes, através do seu Complexo Fundiário Imobiliário Comercial Financeiro (CFICF), buscaram, progressivamente, apropriar-se desses terrenos.

Ações urbanísticas de cunho higienista implementadas pelo Estado, a exemplo das empreendidas pela Liga Social Contra os Mocambos, nos anos 1930 e 1940 (Melo, 1985), foram responsáveis pela "limpeza" dos referidos terrenos, removendo as famílias das classes subalternizadas para outras áreas da cidade, expulsando-as sem garantir-lhes apoio técnico e econômico para estabelecerem-se alhures. Todavia, parte dessas famílias continuou no espaço municipal, ocupando áreas disponíveis e adensando outras áreas de famílias pobres existentes na cidade. (Figura 1). 


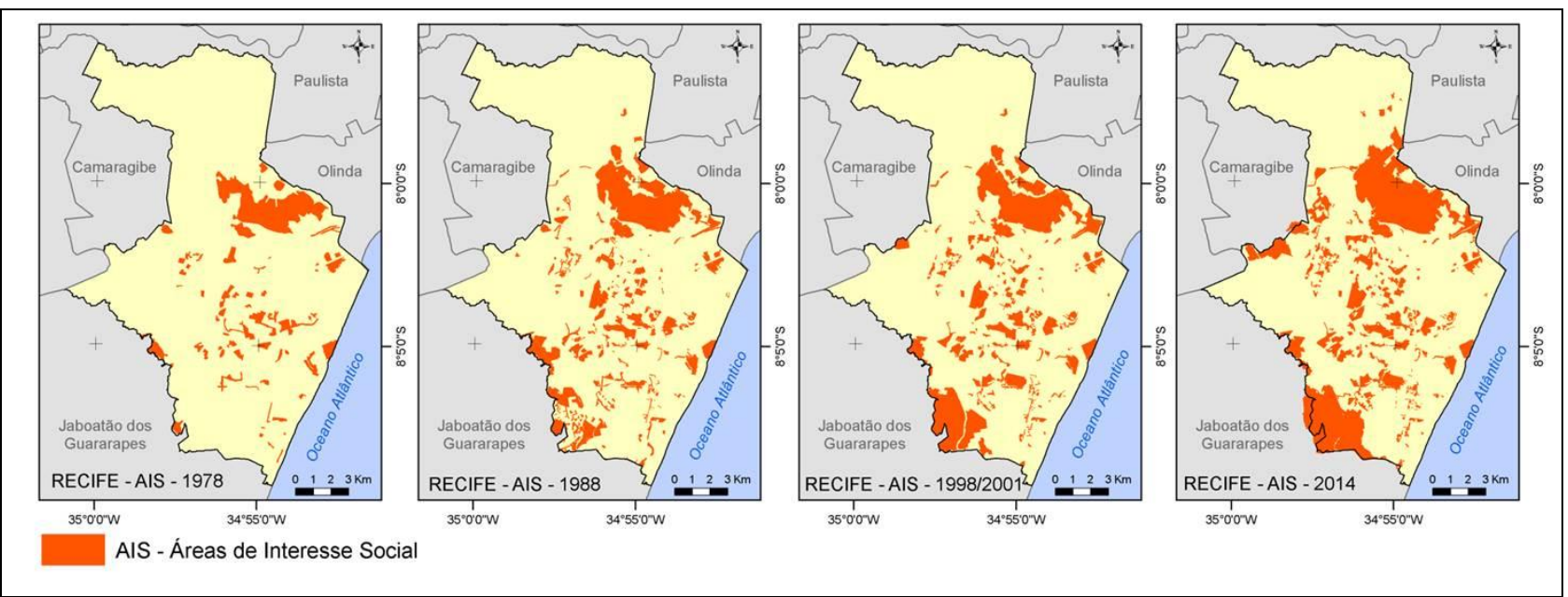

Figura 1 - Recife, cadastramento de áreas de interesse social. Fonte: CONDEPE/FIDEM, SIGAP (2012), RECIFE

(2016). Nota: A periodicidade das observações foi condicionada aos anos disponíveis. Os levantamentos foram realizados com metodologias distintas. Em cada levantamento ocorreram denominações diferentes para essas áreas, por isso Manuela M. P. do Nascimento (Nascimento e Castilho, 2018) achou por bem uniformizá-las, para efeito de comparação, como áreas de interesse social. 0 que interessa é sentir a expansão e o adensamento das referidas áreas no espaço do Recife.

Nota-se, portanto, que as áreas de interesse social ampliaram-se e adensaram-se, entre 1978 e 2014, consolidando um processo que se faz presente há séculos em Recife, não obstante as investidas de apropriação dessas áreas pelos agentes do CFICF. A formação desta estrutura urbana compreende, portanto, o resultado de tensões e conflitos suscitados pelas contradições inerentes ao modo do desenvolvimento histórico-geográfico desigual e combinado capitalista que se materializou e permaneceu no tempo-espaço do urbano no Brasil.

Reitera-se que as CIS acham-se, hoje, fortemente presentes na cidade de Recife (Figura 2), representando lugares que não se acham muito distantes da Área Central e nem das áreas habitadas por famílias pertencentes aos grupos sociais de maior rendimento. Estas se acham, assim, rodeadas por áreas de CIS, as quais, por sua vez, se encontram no interior das áreas de interesse das classes dominantes locais. Isso demonstra que a desigualdade territorial continua fazendo parte da estrutura urbana, inclusive reforçando 0 caráter socialmente injusto da formação territorial brasileira. 


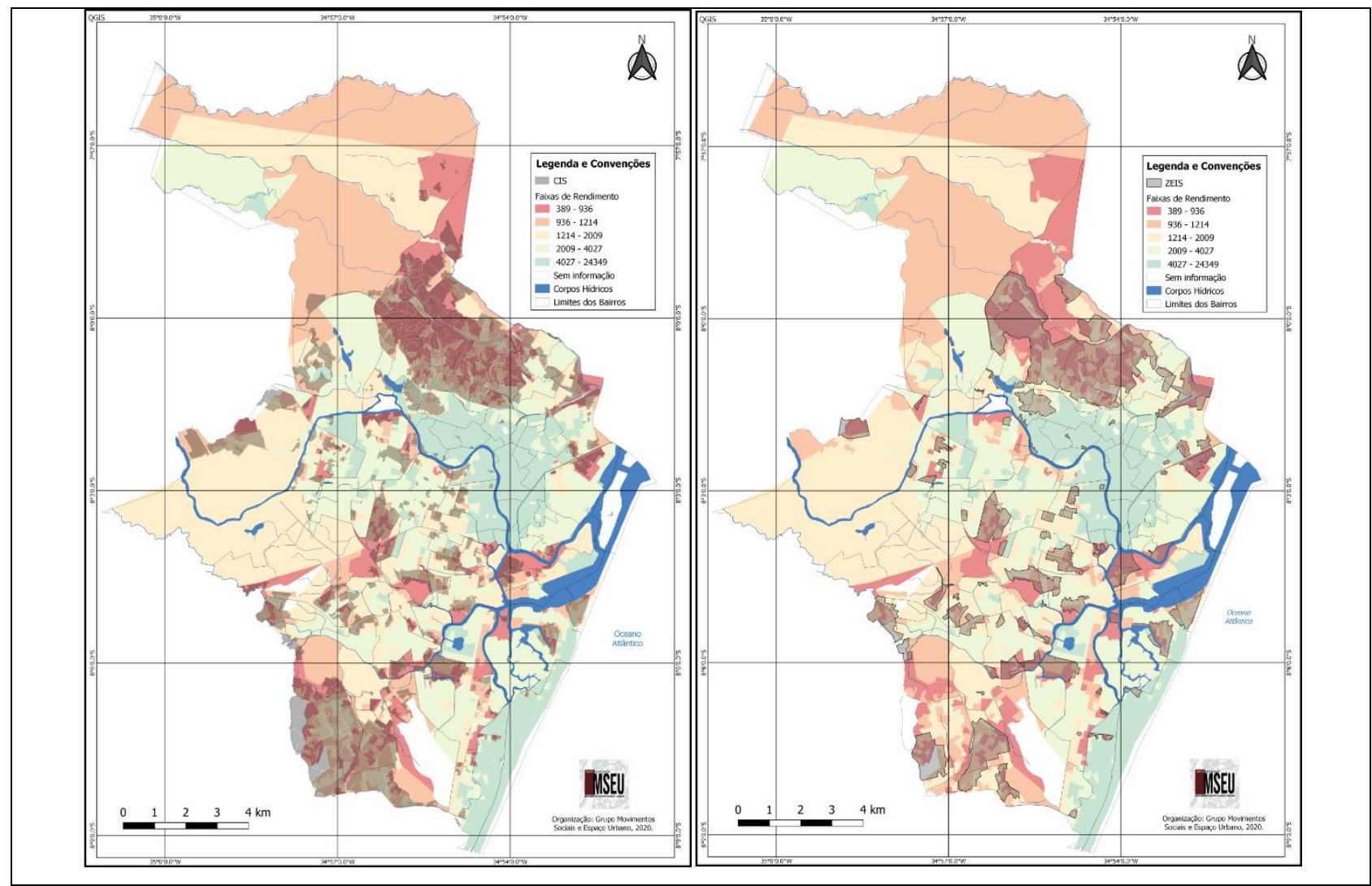

Figura 2 - Recife - Sobreposição do mapeamento de Comunidades de Interesse Social (CIS) das Zonas Especiais de Interesse Social (ZEIS) e do Rendimento mensal por setores censitários (Censo 2010). Fontes: Bases cartográficas/Fontes: Prefeitura da Cidade do Recife, 2016; IBGE/DGC. Base Cartográfica Contínua, ao milionésimo BCIM: versão 4.0. Rio de Janeiro, 2014. Sist. Geodésico de Referência: SIRGAS 2000. Observação: Os limites das bases cartográficas do IBGE e da Prefeitura apresentam diferenças e não foram realizados ajustes, em virtude da finalidade da representação (referentes ao mapa à esquerda). Bases cartográficas/Fontes: Prefeitura da Cidade do Recife, 2016; IBGE/DGC. Base Cartográfica Contínua, ao milionésimo - BCIM: versão 4.0. Rio de Janeiro, 2014. Sist. Geodésico de Referência: SIRGAS 2000. Observação: Os limites das bases cartográficas do IBGE e da Prefeitura apresentam diferenças e não foram realizados ajustes, em virtude da finalidade da representação (referentes ao mapa à direita). Ambas as figuras foram elaboradas e cedidas por Manuela. M. P. do Nascimento, em 2020.

Os moradores das CIS possuem um cotidiano sofrido em função, notadamente, da ausência do conjunto dos serviços públicos sociais fundamentais à concretização do que Santos (1987) chamou de direito ao entorno o qual, por seu turno, constitui condição sine qua non à formação do espaço do cidadão. Os serviços de saneamento (abastecimento de água potável, esgotamento sanitário e coleta de lixo) e a provisão de infraestrutura urbana (vias de acesso, canaletas, obras de drenagem) voltados a uma habitabilidade digna, quando existem nas referidas áreas, atendem de maneira muito precária às necessidades vitais dos/as moradores/as, reduzindo ainda mais a qualidade no que tange à sua habitabilidade. Vale ressaltar que

[...] a moradia adequada é um direito humano, reconhecido em diversos tratados internacionais. Os 7 elementos mínimos do direito humano à moradia adequada, de acordo com o Comentário Geral $n^{0} 4$ do Comitê de Direitos Econômicos Sociais e Culturais, são:

1. Segurança de posse, proteção contra remoção ou despejos e outras ameaças; 
2. Disponibilidade de serviços, materiais, facilidades e infraestrutura, essenciais para a saúde, segurança, conforto e nutrição, etc.;

3. Custo acessível, que não comprometa a realização de outras necessidades básicas;

4. Habitabilidade, proporcionando proteção contra frio, umidade, calor, chuva, vento ou outras amaças à saúde, riscos etruturais e riscos de doença;

5. Acessibilidade, principalmente para os grupos menos favorecidos;

6. Localização, que permita acesso a opções de trabalho, serviços de saúde, escolas, creches e outras facilidades sociais;

7. Adequação cultural, possibilitando a expressão da identidade e diversidade cultural. (Ludermir e Coelho, 2016-2018, p. 13)

Não é preciso fazer muito esforço para verificar que tais elementos mínimos à garantia do direito ao entorno não são respeitados, dificultando, assim, a concretização do uso do território como abrigo e proteção social. A densidade demográfica nas CIS é outro problema digno de menção na medida em que ainda há famílias numerosas para os padrões de uma "sociedade moderna", coexistindo em espaços muito pequenos: casais morando com quatro, cinco ou mais filhos e/ou filhas dividindo áreas com tamanho inferior a $30 \mathrm{~m}^{2}$. Tais condições, sem acesso aos serviços mínimos de abastecimento de água e saneamento suscitam ambientes insalubres e, portanto, vulneráveis a uma série de doenças.

Da mesma maneira, os serviços públicos sociais como os de atenção à saúde (acesso a consultas médicas, exames ambulatoriais, medicamentos, tratamento de doenças, etc.) também têm sido alvo de reclamações contínuas nas mídias locais e nos protestos realizados junto aos órgãos governamentais gestores dos referidos serviços. Estabelecimentos de saúde (postos médicos, policlínicas, upas/upinhas, etc.) até existem nos territórios CIS e ZEIS, porém, o serviços de saúde como direito socialmente conquistado e garantido pela Constituição da República Federativa do Brasil (CRFB) promulgada em 1988 são prestados de maneira muito precária (Castilho, 2015).

As condições sociais acima ressaltadas inerentes ao território usado influem decerto na forma através da qual uma pandemia atinge os diversos lugares da cidade, ou seja, se por um lado, a pandemia causada pela COVID-19 atinge a todos os lugares ao mesmo tempo; por outro, ela não os atinge da mesma maneira. Em outras palavras, a condição de cada lugar, em termos da promoção do acesso à habitação e a serviços públicos sociais de saneamento e atenção à saúde bem como o de transportes para a coletividade social, faz uma significativa diferença e isto em todas as escalas geográficas.

\subsection{Espaço propício a pandemias}

A ocorrência e reincidência de pandemias não constituem eventos novos no mundo. Atualmente, vivencia-se mais uma pandemia a qual acontece em proporções gigantescas, desta vez provocada por um vírus desconhecido e letal causador da COVID-19; e, mais uma vez, os países não conseguem evitar o crescente número de óbitos, evidenciando que aprenderam pouco a lição com experiências passadas. 
Para combater a propagação da COVID-19, observa-se que, na maioria dos casos, os governos utilizamse novamente de procedimentos semelhantes aos utilizados em outros momentos históricos de surtos virais a exemplo do que ocorrera no início do século XX, que ficou conhecido como o da "gripe espanhola", dentre outros casos ocorridos no curso da história da civilização humana.

A aparente repetibilidade e previsibilidade serial decorre do fato da ação das coisas no tempo serem, intrinsecamente humanas. É esta humanidade que nos leva, no exercício da memória, a nos ver nas coisas e no tempo. A desigualdade econômico-social, presente há 100 anos na "gripe Espanhola" e nos 1000 anos anteriores, esta, não é cíclica e nem repetida: parece permanência a desafiar as sociedades. Uma história dos usos sociais da água exemplarmente nos denota escolhas pela exclusão de parte das populações ao direito igualitário aos bens naturais, econômicos e sociais, na história da humanidade. (Meneses, 2020, p. 49)

Nunca se aprende, ou melhor, não se quer aprender com as experiências de pandemias que, por seu forte grau de letalidade, provocaram a morte de milhares e mesmo milhões de pessoas em tempos passados. Mas por que este problema se repete? Onde reside a sua principal causa? Na expansão espacial do vírus em si ou na forma mediante a qual as sociedades usam os seus respectivos territórios.

A história tem demonstrado que a escolha pelo modo capitalista de produção social, hoje de tendência claramente neo-liberal, deixa diversos lugares - dos países de capitalismo avançado e periférico - vulneráveis aos seus impactos negativos. O território usado em Recife, tal como colocado na seção anterior, acha-se vulnerável às vicissitudes nefastas decorrentes da referida escolha - especulação imobiliária, privatização dos serviços sociais públicos como os de saúde, etc. - as quais lhes ameaçam com frequência, suscitando crises econômicas e sanitárias, algumas vezes acontecendo simultaneamente.

Defende-se, portanto, que tais crises não são causadas meramente pela propagação espacial da COVID-19 per se, mas, simultaneamente, pela lógica da racionalidade técnico-instrumental capitalista vigente no mundo, aprofundando o que Harvey (2004) chama acumulação por despossessão, a qual norteia 0 atual uso social do território em que o Estado perde sua capacidade de construir infraestrutura social e distribuir rendas e os/as trabalhadores/as fragilizam-se pela corrosão dos seus salários, pelo aumento do desemprego e pelo poder de articular-se em seus sindicatos. Por outro lado, tais processos fortalecem a acumulação de capitais em escala global desmontando o que se conseguiu construir como Estado do Bem-Estar social garantidor de direitos como a legislação trabalhista e o sistema de previdência social. A privatização, por exemplo, dos sistemas públicos de saúde constitui uma das consequências negativas do referido processo de acumulação. Tenta-se esconder esta verdadeira causa para não manchar o propósito da lógica hegemônica, destarte, a realidade é muito mais complexa do que parece.

Em todo o espaço geográfico onde se faz presente, como acentua Harvey (2013), o capitalismo sempre busca transformar em mercadoria tudo o que encontra no seu caminho, com a finalidade, notadamente, de 
gerar riquezas a todo custo. Daí por que, seus corifeus nunca negligenciam formular e propagar discursos com a finalidade de reforçar a ideologia que ratifica os seus verdadeiros propósitos. Trata-se de uma perspectiva de relações de produção-circulação-distribuição-consumo que se expande e se reproduz, aceleradamente, pelo mundo há cerca de 520 anos, negando qualquer possibilidade de mudança de tal sentido.

$\mathrm{Na}$ medida em que as relações acima referidas consolidam-se no tempo-espaço do mundo, principalmente sob as fases de predominância da razão neo-liberal de construção territorial, os lugares, mormente em função da acumulação por despossessão, tornam-se cada vez mais vulneráveis, ou seja, frágeis à cobiça dos interesses capitalistas, enfraquecendo-se. Os lugares são frequentemente atacados pelos imperativos de uma lógica que se baseia no crescimento econômico voltado, preponderantemente, para a geração de riquezas a qual constitui a principal meta a ser atingida, mesmo que isso aconteça às custas da vida na Terra. Sob tais parâmetros de produção territorial, o meio geográfico fica sujeito às consequências negativas desse modelo perverso de mundo.

A maneira pela qual, atendendo aos propósitos das classes dominantes, a celeridade e intensidade dos processos econômicos usam o território, incluindo aí o uso da natureza, percebendo-se fora e separadas desta dimensão vital da humanidade, possui relação direta com o aparecimento de doenças que nos têm atingido. Isto nos leva a reconhecer, em escala global, problemas relativos aos descaminhos ocorridos entre ecologia e economia.

Já se sabe que $60 \%$ das doenças infecto contagiosas que atingem o homem têm origem em animais não humanos (as zoonoses), sendo que "mais de dois terços deles são originários da vida selvagem". [...] Há apenas uma ou duas décadas [...], "acreditava-se amplamente que florestas tropicais e ambientes naturais intactos repletos de fauna exótica ameaçavam os seres humanos ao abrigar os vírus e patógenos que levam a novas doenças em seres humanos como Ebola, HIV e dengue. Atualmente [...], pesquisadores pensam que é realmente a destruição da biodiversidade pela humanidade que cria as condições para o surgimento de novos vírus e doenças como COVID-19. (Sá, 2020, p. 1)

A questão dos problemas provocados pelo afastamento entre natureza e sociedade, em função da imposição dos imperativos da lógica da racionalidade técnico-instrumental capitalista de tendência neo-liberal, poderia ser resolvida pela recusa imediata da ideia de que a natureza constituiria uma dimensão alheia e separada da cultura, da economia e do cotidiano da sociedade. Fundamentando-se em uma perspectiva teórico-empírica dialética e relacional da ligação metabólica dos homens e das mulheres com a natureza, Harvey (2020, p. 15) reconhecera que

O capital modifica as condições ambientais de sua própria reprodução, mas o faz num contexto de consequências não intencionais (como as mudanças climáticas) e contra as forças evolutivas autônomas e independentes que estão perpetuamente remodelando as condições ambientais. Deste ponto de vista, não existe um verdadeiro desastre natural. Os vírus mudam o tempo todo. Mas as circunstâncias nas quais uma mutação se torna uma ameaça à vida dependem das ações humanas. 
A respeito, ainda, da mesma questão supramencionada, no âmbito da ideia da transformação de uma natureza amiga em uma natureza hostil ao homem, acentuou Santos (1992, p. 96-97) que

A história do homem sobre a Terra é a história de uma ruptura progressiva entre o homem e 0 entorno. Esse processo se acelera quando, praticamente ao mesmo tempo, o homem se descobre como indivíduo e inicia a mecanização do Planeta, armando-se de novos instrumentos para tentar dominá-lo. A natureza artificializada marca uma grande mudança na história humana da Natureza. Agora, com a tecnociência, alcançamos o estágio supremo dessa evolução.

Segundo Carvalho (2012, p. 92), "As doenças infecciosas emergentes [...] como SARS, são cada vez mais comuns. De acordo com a [...] OMS [...], desde a década de 1970, cerca de 40 novas [zoonoses] foram descobertas". São, portanto, as ações humanas que, através da invasão do habitat de animais selvagens, desmatando para construir estradas, cidades, barragens e implantar atividades de mineração e agronegócio, bem como do aumento das viagens aéreas, da difusão do tráfico de vidas selvagens, etc., têm causado frequentes surtos de doenças infecciosas. Defendendo a tese segundo a qual as pandemias letais são provenientes de alterações genéticas que tornam os vírus capazes de infectar os homens, Ujvari (2012, p. 161) acentua que a dinâmica dos fluxos econômicos também influi na propagação de doenças dentre as quais se acham as causadas por vírus.

Com a globalização do transporte, principalmente após o período industrial, essas pandemias ganharam força. O Brasil conheceu, em 1889 e 1890, um vírus da gripe surgido no sul da Rússia que se alastrou pelo continente europeu. Embarcações a vapor circularam o vírus com maior eficiência. Pessoas doentes embarcaram em um paquete na cidade de Hamburgo. Desembarcaram em Salvador. Suas tosses e corizas transferiram o vírus para quase metade dos habitantes da cidade. A doença alastrou-se pelo litoral nordestino e alcançou o Rio de janeiro. Levou D. Pedro II para a cama. Não deixaria vestígios, porém, para estudarmos com a ciência do século XX. Ao contrário do que ocorreu com a próxima e mais grave, a epidemia da gripe espanhola de 1918. (UJVARI, 2012, p. 161)

Reforça-se, portanto, a ideia segundo a qual, tal como assumido anteriormente, a raiz do problema ora em foco encontra-se, preponderantemente, na própria lógica neo-liberal do acontecer histórico do capitalismo no mundo, suscitando, frequentemente, momentos de crises econômicas e sanitárias cujos impactos trágicos são inevitáveis².

As crises, enfim, suscitam a necessidade de compreender o verdadeiro sentido do modelo capitalista vigente de ser e pensar, a fim de contribuir para a conscientização da sociedade acerca das contradições desse modelo, as quais têm ameaçado a existência da vida humana na Terra. Com efeito,

\footnotetext{
2 Afastamo-nos, portanto, das visões conspiratórias e simplistas de mundo segundo as quais a COVID-19 tratar-se-ia do vírus causador da "gripe chinesa" propagada, propositalmente, para finalidades geopolíticas, bem como de um surto viral devido a patógenos liberados de laboratórios e/ou ações de pesquisa voltada para a produção de armas químicas. Visões desse tipo só interessam aos poderes ora instituídos que desejam mascarar aspectos da realidade que poderiam, se descobertos, desmanchar a ideologia reforçadora dos seus verdadeiros propósitos.
} 
O surto [da COVID-19] expôs instantaneamente a divisão de classes na saúde americana. Aqueles com bons planos de saúde que também podem trabalhar ou ensinar de casa estão confortavelmente isolados, desde que sigam salvaguardas prudentes. Os funcionários públicos e outros grupos de trabalhadores sindicalizados com cobertura decente terão de fazer escolhas dificeis entre renda e proteção. Enquanto isso, milhões de trabalhadores com baixos salários, trabalhadores rurais, desempregados e sem teto estão sendo jogados aos lobos. (Davis, 2020, p. 9)

No Brasil, a questão de classe, como colocado anteriormente, tem permanecido no curso do processo da sua formação histórico-geográfica visto que a lógica do modo de produção capitalista pela qual o país optou continua a mesma, ou seja, priorizando os interesses econômico-financeiros. Young (2020) acentua que persiste a negação de direitos, cidadania e vida aos negros e aos índios e que os interesses econômicos sobrepõem-se aos demais, razão por que tais povos estão entre os que mais sofrem com a COVID-19. Por isso,

Se no Brasil do século XIX as principais vítimas das epidemias e pandemias foram os escravizados e os pobres das cidades e do campo, hoje, os mais vulneráveis à pandemia do Covid-19 são os seus herdeiros históricos: os favelados, os presidiários e a população em situação de rua. Nunca é demais lembrar que a abolição da escravidão [...] se deu sem nenhuma política de integração dos ex-escravizados à sociedade. (Guimarães, 2020, p. 103)

Prestando mais atenção às contradições acima referidas, considera-se que parte da sociedade se autoconscientiza da relevância das pautas que têm sido levantadas por entidades sociais críticas - a exemplo dos sindicatos e dos movimentos sociais - as quais, aliás, nunca se calaram diante da insensatez no que se refere à perversidade inerente à lógica do capitalismo neo-liberal. A este respeito, vale ressaltar

[...] o que os funcionários do hospital da França, lutando ao longo do ano passado, têm dito repetidamente: que o hospital público é vítima de políticas de estrangulamento financeiro, tornando-o cada vez menos capaz de cumprir as suas tarefas de acolhimento e cuidado dos pacientes; mas que também é vítima de uma medicina liberal da cidade que, em grande parte, vira as costas à sua missão, enviando pacientes para o hospital público que inicialmente estavam sob seus cuidados; enquanto as clínicas privadas prosperam com os excessos de taxas que selecionam uma "clientela" que evita a dupla armadilha anterior. Tanto que, quando o choque de uma pandemia atinge, é todo este sistema, deliberadamente dilapidado, que se revela incapaz de lidar com a situação forçando os prestadores de cuidados a separar os pacientes de acordo com a sua expectativa de sobrevivência... e idade. Como os cirurgiões fazem em tempo de guerra nos hospitais de campanha, na retaguarda da linha de frente! (Bihr, 2020 , p. 26)

Outros países europeus - tais como: Itália, Espanha e Reino Unido - revelaram os efeitos perversos da sua submissão, sobretudo a partir do contexto de consolidação da razão neo-liberal de uso do território, preterindo, com base na ideia de redução de gastos, os investimentos em serviços públicos sociais e priorizando a geração de riquezas sob os parâmetros do capitalismo. Nesse contexto, investimentos em aeroportos, agências de viagem, hotéis, restaurantes, centros turísticos e de lazer e parques temáticos tornaram-se muito mais presentes nas cidades do que em hospitais devidamente equipados e laboratórios de pesquisa em saúde pública. Portanto, mesmo em lugares reconhecidos como de Primeiro Mundo que possuem - ou possuíram - 
"Estado Protetor", deixou-se de investir, como antes, em serviços de atenção à saúde, privatizando-os, o que contribuiu para os atuais cenários trágicos ocorridos em função da propagação da pandemia da COVID-19.

A situação torna-se ainda pior em lugares onde, quando muito, houve, em alguns momentos da história, experiências de um Estado Desenvolvimentista, pelas quais o direito ao entorno nunca se concretizou e, por sua vez, a condição de cidadania ainda é um sonho muito distante de ser conquistado por todos e todas. Basta prestar um pouco mais de atenção para a forma pela qual bens de consumo coletivo como saneamento, habitação, serviços públicos sociais de atenção à saúde e transportes são providos para as classes sociais subalternizadas - visando ao lucro acima de tudo - que logo se compreende o que se está colocando.

Acrescenta-se um fato de ordem conjuntural que complica a situação brasileira, ou seja, o atual governo federal, desprovido de espírito republicano, não consegue enxergar os seus erros e, assim, não aceita, mesmo diante das evidências trágicas dos efeitos da pandemia, mudar a sua postura economicista para uma mais humana. Não obstante, principalmente em função da contradição inerente ao movimento histórico da sociedade, este mesmo governo foi obrigado a realizar uma significativa distribuição de renda através dos chamados programas emergenciais voltados para os/as trabalhadores/as mais vulneráveis.

A enorme diferença entre os modelos de uso social do território implica não somente em processos distintos de organização territorial, configurando diferentes territorialidades; mas, ao mesmo tempo, em maneiras distintas de vulnerabilidade social, de enfrentamento às adversidades e, por conseguinte, de formas de superar tais condições. Daí por que, levanta-se como hipótese a ideia de que mesmo tendo sofrido muito com a pandemia da COVID-19, justamente por já terem tido uma experiência de Estado Protetor, as referidas nações europeias, apresentam-se com condições mais efetivas de enfrentamento e combate à pandemia em epígrafe.

O problema, entretanto, parece difícil de ser resolvido a curto prazo em função, sobretudo, do peso da ideologia hegemônica para a qual a celeridade e intensidade dos processos de urbanização e de expansão do agronegócio por lugares do mundo constitui uma estratégia das relações capitalistas. No caso dos lugares que se situam em regiões tropicais e subtropicais nas quais a pobreza e o desmatamento expandem-se a todo vapor, desrespeitando as formas de controle das instituições públicas nacionais historicamente criadas, a situação torna-se ainda mais grave.

Em todo o Planeta, a manifestação da pandemia da COVID-19 inicia-se e propaga-se a partir de um dos centros urbanos mais dinâmicos do espaço mundial contemporâneo. Afinal, Lefèbvre (1974) demonstrara, há décadas, que os centros - como espaços de encontros promovedores da centralização e da centralidade constituem espaços cruciais do acontecer histórico do capitalismo e, por sua vez, de tudo o que se acha intrinsecamente relacionado a este modo de produção. 
Tais lugares constituem espaços da produção e reprodução das relações capitalistas de produçãocirculação-distribuição-consumo inerentes ao mundo moderno e, concomitantemente, da manifestação dos seus impactos perversos. Os centros constituem as áreas urbanas, ou seja, os lugares, segundo Santos e Silveira (2001), de forte densidade do meio técnico-científico-informacional que propiciam grande fluidez, capacidade de influência e rapidez, enfim, espaços luminosos. Estes constituem, assim, os espaços dispersores da COVID-19, o que é estimulado pelo modo como se dá o uso do território.

No Brasil, da mesma maneira que acontece na escala do mundo, são os espaços luminosos que concentram as mais significativas ocorrências da pandemia da COVID-19, as quais se vão expandindo pelos seus respectivos entornos à medida que os contatos sociais se estabelecem através das vias de circulação que estruturam o processo de organização do espaço urbano. (Figura 3).
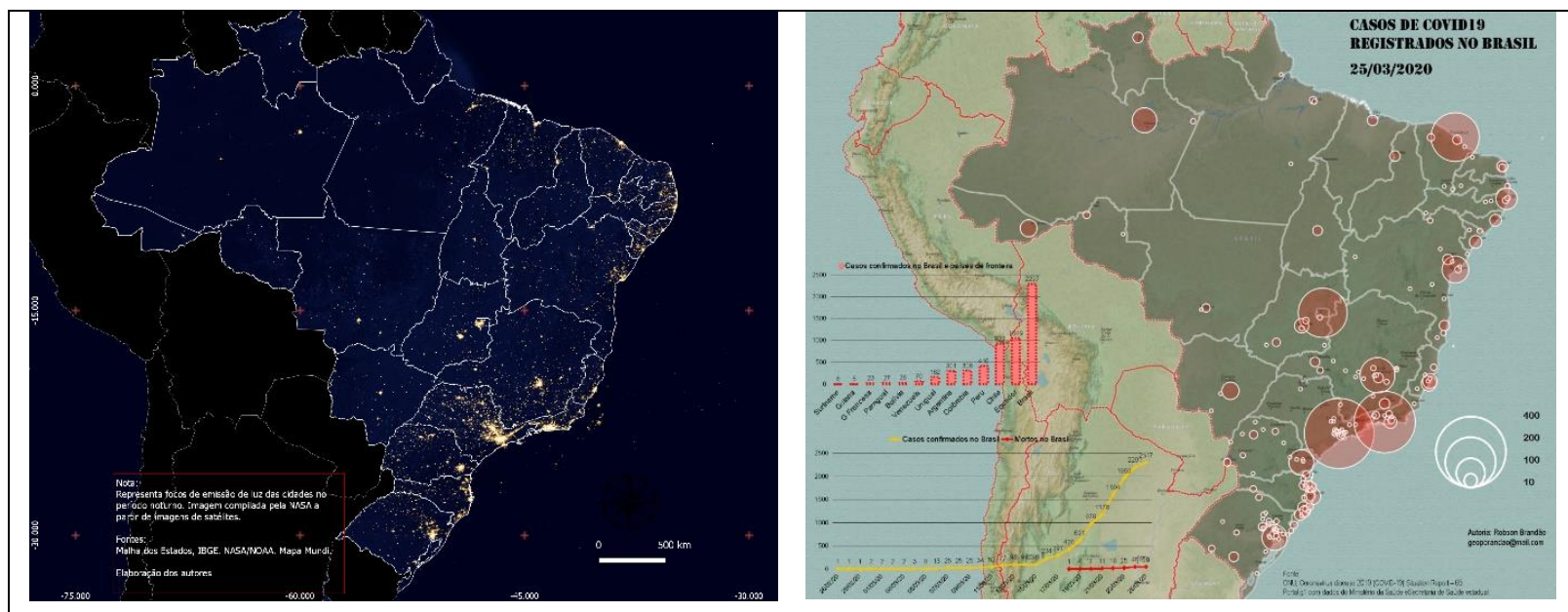

Figura 3 - Brasil, espaços luminosos; ocorrências dos casos da COVID-19. Fontes:

Figuras cedidas por Robson José Alves Brandão, 2020, orientado nosso no PRODEMA-UFPE.

Paralelamente, tendo em vista que, nos tempos atuais, existe intensa superposição em termos de modalidade de transportes de alta velocidade interligando os territórios entre si e com suas respectivas hinterlândias, associada à acessibilidade ao sistema de crédito que facilita a realização das viagens internacionais acelerando o ritmo dos fluxos econômicos a todo custo, compreende-se a razão pela qual o surto da doença em epígrafe espalhou-se tão rapidamente pelo mundo.

Trata-se do uso dos territórios segundo os interesses das relações puramente capitalistas de produçãodistribuição-circulação-consumo de maneira mais célere e intensiva. Contrapostos aos espaços luminosos, têm-se os espaços opacos, ou seja, os territórios usados, segundo ainda Santos e Silveira (2001), por aqueles que não possuem as mesmas condições em termos de fluidez, capacidade de influência e rapidez exigidas pelas relações capitalistas atuais a exemplo dos que moram em CIS, mas que não deixam de ser atingidos pelos fluxos inerentes à dinâmica econômica. 
Não dispondo da qualidade devida e exigida em termos de habitabilidade, saneamento, serviços públicos sociais de atenção à saúde, de transportes e acesso ao mercado de trabalho formal, os espaços opacos tornam-se muito mais vulneráveis aos efeitos perversos do capitalismo, incluindo os decorrentes da pandemia da COVID-19, o que é facilmente visível quando se escuta e dá voz às pessoas que as classes dominantes insistem em não enxergar.

Segundo as falas das pessoas escutadas, destacando os conteúdos mais proferidos por elas, ou seja, aqueles que se repetiram nas falas de quase a totalidade delas: "[...] não tem água em nossas casas e a gente tá fazendo das tripas coração pra conseguir água pra lavar as mãos" (Moradora de uma CIS no bairro Pina); "A falta de água faz com que muita gente use a água do rio [...], mas ela é suja e tenho medo de usá-la" (Moradora de uma CIS no bairro Boa Vista); "As casas aqui na Comunidade são muito pequenas [...] na minha, eu moro numa casa que só tem uma sala, um quarto e um banheiro e tenho cinco filhos [...], imagina se um de nós pegar esse vírus..." (Moradora de uma CIS no bairro Boa Viagem); "Eu moro numa casa de uma sala, dois quartos, um banheiro [...] tudo isso pra mim, meu marido, cinco filhos e minha sogra que tem 80 anos de idade" (Moradora de uma CIS no bairro Boa Viagem); "Nossa casa é muito pequena e só tem uma janela e uma porta, isso dificulta a entrada do vento [...], se alguém daqui pega esse vírus tamos fritos, [...] o senhor tá vendo que somos 7 pessoas morando nesse vão de apenas um quarto e um banheiro" (Moradora de uma CIS no bairro Santo Amaro); "Não temos água encanada em casa, estamos usando água do rio, mas a gente fica com receio porque essas águas não são limpas" (Moradora de uma CIS do bairro Pina); "[...] tenho muito medo de sair porque na televisão passa todas aquelas covas onde se está enterrando muita gente junta por dia, mas o que fazer, né? [...] Preciso pegar o auxílio porque não tenho nada pra dar a meus filhos que estão em casa..." (Trabalhador em uma fila da Caixa Econômica Federal-CEF, no bairro Encruzilhada); "Se eu pudesse não saía de casa porque não quero pegar a doença e nem levar ela pra meus parentes de casa, mas tenho necessidade desse dinheirinho pra que minha família não passe fome" (Trabalhadora em uma fila da CEF, no bairro Engenho do Meio); "Olhe, a situação dos ônibus é sempre ruim, os ônibus parece que carrega boi de tão cheio, e agora com o coronavírus está pior porque a gente corre risco de pegar esse danado e morrer ou de levar ele para casa e passar para um parente (Trabalhador no Terminal de Integração da Macaxeira); "Justamente agora quando devia ter mais ônibus pra gente viajar sentado e separado, tá assim, cheio de gente [...] e arriscando a vida da gente todo dia, mas precisamos ir trabalhar, que fazer né?" (Trabalhadora no Terminal de Integração Joana Bezerra); "Se eu pudesse ficava em casa para não arriscar minha vida e a dos meus pais e filhos [olhos cheios de lágrimas], mas tenho que ir trabalhar, minha patroa disse que não tem condição de me pagar se eu não for ao trabalho (Trabalhadora no Terminal de Integração Joana Bezerra); "Era pra tá tudo fechado, o governo até tentou controlar no início mas depois escutou os donos de empresas que só pensam neles [...], aí as lojas abriram e a gente teve que trabalhar nesse risco todo de pegar o vírus" (Trabalhador em rua comercial 
do bairro São José); e "Eu queria tá em casa cuidando pra meu pessoal não pegar esse bicho [a COVID-19] mas não posso deixar de vir pra loja senão o patrão me demite (Trabalhadora em rua comercial do bairro Santo Antônio).

O conteúdo das falas acima demonstra que as pessoas estão cientes do perigo que pode acometer os seus lares, porém, dispondo de condições precárias nos seus diversos lugares de existência, são obrigadas a exporem-se à COVID-19 a fim de conseguirem sobreviver. O medo com relação ao uso da água do rio, em função da poluição, para a higienização pessoal remete-nos, também, a uma consciência da necessidade de cuidar melhor do seu meio geográfico. 0 medo de não ter acesso aos meios mínimos para a higienização pessoal e do lar, o medo de terem que tomar ônibus cheios de gente impedindo a necessidade do estabelecimento da distância mínima para evitar o contágio e o medo de ter que sair de casa para não perderem seus postos de trabalho sob a pressão dos proprietários dos estabelecimentos comerciais demonstram a grande apreensão das classes subalternizadas no atual momento da pandemia da COVID-19.

Em Recife (Figura 4), nota-se que a concentração dos infectados pela COVID-19 achava-se, em princípio, nas duas principais centralidades socioeconômicas locais. Foi a partir destas áreas que os casos de ocorrência da doença espalharam-se, atingindo tragicamente os lugares das classes subalternizadas, tal como aconteceu em outras cidades brasileiras. Barbosa e Teixeira (2020, p. 69) reconheceram processo semelhante no Rio de Janeiro ao constatarem o movimento da COVID-19 "[...] dos bairros de classes médias com maior renda econômica, disponibilidade de equipamentos e valorização imobiliária [...] para os subúrbios, favelas e periferias cariocas".

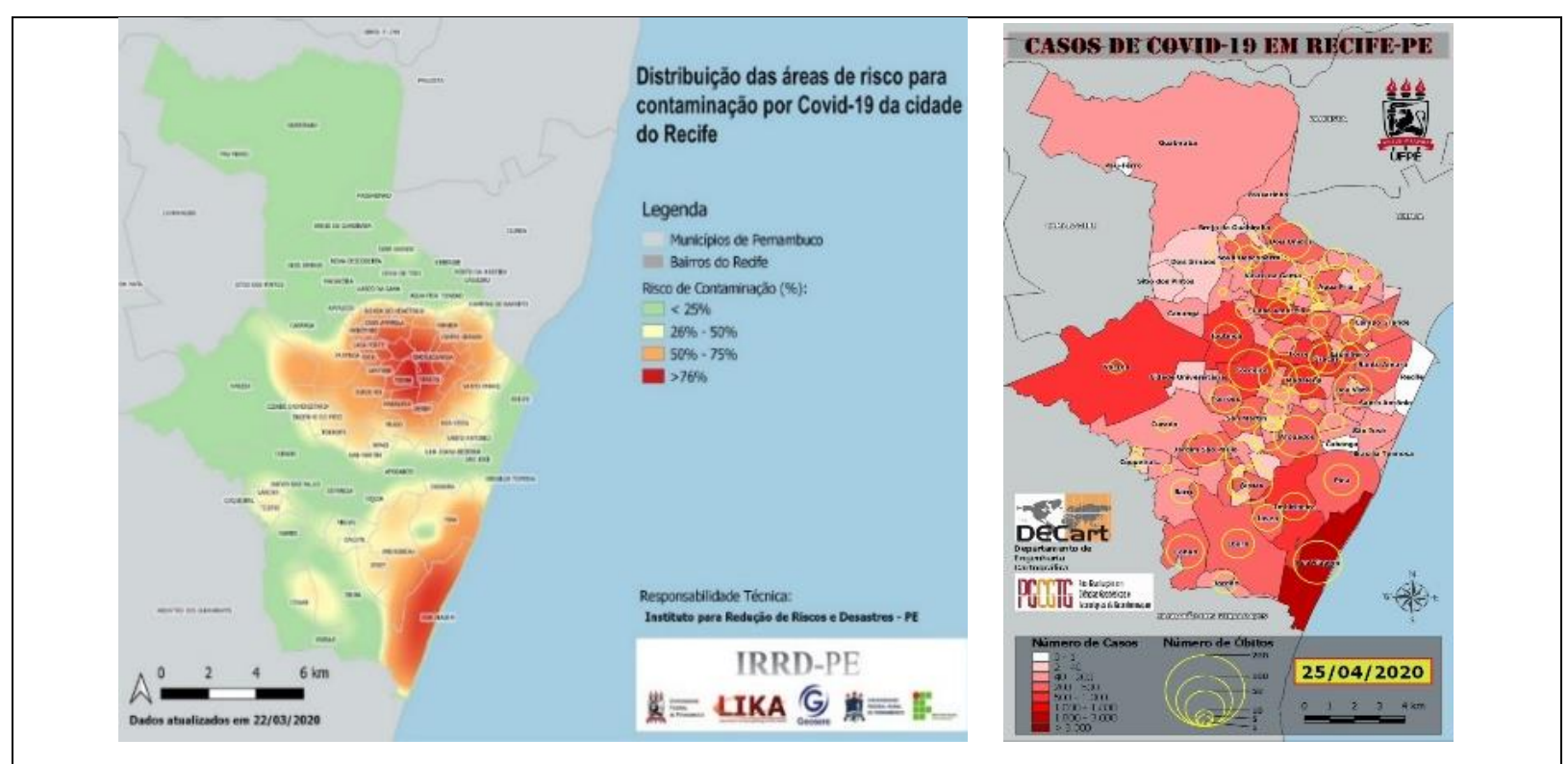

Figura 4 - Município do Recife: epicentros iniciais da pandemia da COVID-19 (à esquerda) e áreas atingidas em cerca de um mês. Fontes: IRRD-PE 22/03/2020 e DECART/PGCGTG/UFPE 25/04/2020, respectivamente. 
Os centros dispersores da doença em questão constituem os lugares que, por constituírem os principais espaços luminosos da cidade, abrigam a maior parte das pessoas provenientes das classes dominantes locais, ou seja, os homens e as mulheres que viajaram ao exterior e trouxeram a COVID-19 para a cidade. Todavia, trata-se das pessoas que, tendo tido acesso ao conjunto de bens e serviços de consumo coletivo necessários à vida social, possuem condições de habitabilidade mais próximas do que se concebe como direito à viver com, pelo menos, um mínimo de dignidade, para combater, ao nível individual, os efeitos nefastos da pandemia.

São estas pessoas, portanto, que reúnem as condições necessárias para livrarem-se da ameaça de contrair 0 vírus em epígrafe na medida em que conseguem permanecer mais tempo dentro das suas residências, inclusive continuando a realizar suas atividades cotidianas utilizando-se das novas tecnologias disponíveis nas diversas escalas territoriais do meio técnico-científico-informacional, diferentemente do que acontece com as pessoas das classes subalternizadas que vivem nos espaços opacos.

Estas últimas, como revelado pelas suas próprias falas, se permanecerem confinadas em casa sem alguma ajuda do Estado, podem até mesmo morrer de fome, o que nos remete a uma clara questão de classe social, a qual, negada pelos teóricos neo-liberais, ainda é muito forte na sociedade contemporânea, apresentando influência nas relações socialmente estabelecidas no território.

Há, por exemplo, a questão de quem pode e quem não pode trabalhar em casa. Isto agrava a divisão social, assim como a questão de quem pode se isolar ou ficar em quarentena (com ou sem remuneração) em caso de contato ou infecção. Exatamente da mesma forma que aprendi a chamar os terremotos da Nicarágua (1973) e da Cidade do México (1995) de "terremotos de classe", assim o progresso da COVID-19 exibe todas as características de uma pandemia de classe, de gênero e raça. Embora os esforços de mitigação estejam convenientemente camuflados na retórica de que "estamos todos juntos nisso", as práticas, particularmente por parte dos governos nacionais, sugerem motivações mais sinistras. A classe trabalhadora contemporânea nos Estados Unidos (composta preponderantemente por afro-americanos, latinos e mulheres assalariadas) enfrenta a desagradável escolha da contaminação em nome do cuidado e da manutenção de elementos-chave de provisão (como supermercados) abertos ou do desemprego sem benefícios (como cuidados de saúde adequados). Assalariados (como eu) trabalham em casa e recebem seu pagamento como antes, enquanto os CEOs voam em jatos e helicópteros particulares. (Harvey, 2020, p. 21-22)

Com efeito, a COVID-19 é uma doença que atinge a todas as classes sociais, mas não as atinge de maneira igual, revelando a desigualdade inerente à sociedade de classes. Os lugares nos quais as classes subalternizadas moram e vivem - os espaços opacos por elas usados - são desprovidos das condições mínimas de existência, apresentando, secularmente, os mesmos problemas, quais sejam, habitações insalubres, inexistência e/ou precariedade das redes de saneamento - provisão de água potável, esgoto e coleta de lixo - e dos serviços públicos de atenção à saúde e transporte.

Ao fim e ao cabo, por mais que se afirme que o vírus não escolha classe social, esta premissa deve ser rechaçada, pois ela não pode ser "democrática" numa sociedade marcada pela desigualdade, em que o acesso ao trabalho, saúde, educação, bens e serviços não são minimamente os mesmos para todos; da mesma forma que os efeitos da doença, que 
provoca(ra)m consequências na maioria das vezes completamente díspares para cada faixa social, reproduzem ainda mais a desigualdade. (Santos, 2020, p. 158)

Por isso, em uma sociedade de classes, no momento em que as chances de contágio são grandes, cabe ao Estado, na escala do tempo curto, empreender um conjunto de ações com vistas a garantir a preservação da vida humana para todos e todas; e, no tempo longo, continuar investindo pesadamente em obras de infraestrutura urbana e serviços públicos sociais na perspectiva do uso do território como abrigo e proteção sociais.

\subsection{Ações socialmente consequentes}

Diante da insustentabilidade do território usado pelos interesses puramente econômicos, faz-se mister implementar um conjunto de ações socialmente consequentes que eliminem as desigualdades e injustiças territoriais. Nesta perspectiva, visando à promoção de uma habitabilidade humanamente sustentável, ressaltase o investimento na expansão - quantitativa e, ao mesmo tempo, qualitativa - dos serviços de saneamento, atenção à saúde e transportes públicos sociais, associados a formas justas e dignas de habitação para a coletividade.

Em sendo assim, as classes subalternizadas conquistariam seu direito ao entorno e não ficariam, como sempre, tão dependentes dos pacotes emergenciais de auxílio. Por outro lado, garantido o direito ao entorno, em vez de se gastar dinheiro e energias para a instalação de hospitais de campanha e infraestruturas correlatas, as ações governamentais poderiam concentrar seus esforços para controlar, de maneira mais eficaz, a expansão das pandemias, dentre outras tragédias, que vierem a ocorrer.

Faz-se mister reconhecer as especificidades concernentes ao território usado que suscitam formas diferentes de articulação e mobilização sociais em diversos lugares do mundo, sobretudo naqueles em que se apresenta maior vulnerabilidade em razão do fato de terem conhecido modos mais céleres e intensivos de consumismo que explodiram depois do choque de 2007-8, levando-os a consequências catastróficas.

\footnotetext{
A torrente de investimentos em tais formas de consumismo teve tudo a ver com a máxima absorção de volumes de capital exponencialmente crescentes em formas de consumismo que tiveram o menor tempo de rotatividade possível. 0 turismo internacional era emblemático. As visitas internacionais aumentaram de 800 milhões para 1,4 bilhões entre 2010 e 2018 . Esta forma de consumismo instantâneo exigiu investimentos maciços em infra-estruturas de aeroportos e companhias aéreas, hotéis e restaurantes, parques temáticos e eventos culturais, etc. (Harvey, 2020, p. 19-20)
}

São dos lugares como espaços opacos que nos chegam ações - a partir da crítica às ideias segundo as quais a "normalidade" deverá ser retomada depois que tudo tiver passado - de caráter alternativo, segundo Acosta (2016), de se imaginar e praticar outros mundos possíveis. Isso acontece, notadamente, porque a normalidade à qual se tem referido, através da mídia comercial, é justamente a que se sustentava em formas 
de uso do território que de certa feita naturalizam a devastação da natureza e a miséria de muita gente visando beneficiar a todo custo os interesses hegemônicos do capitalismo.

O que estamos vivendo pode ser a obra de uma mãe amorosa que decidiu fazer o filho calar a boca pelo menos por um instante. Não porque não goste dele, mas por querer the ensinar alguma coisa. "Filho, silêncio!". A Terra está falando isso para a humanidade. E ela é tão maravilhosa que não dá uma ordem. Ela simplesmente está pedindo: "Silêncio!". Esse é também o significado do recolhimento. [...] É hora de contar histórias às crianças, de explicar a elas que não devem ter medo. Não sou um pregador do apocalipse, o que tento é compartilhar a mensagem de um outro mundo possível. Para combater esse vírus, temos de ter primeiro cuidado e depois coragem. (Krenak, 2020, p. 9)

Defendendo que não voltemos à normalidade ressaltada pela mídia comercial, este autor busca fazer valer a razão de ter havido tanto sofrimento na Terra, alertando-nos para a necessidade de se reconstruir 0 mundo na perspectiva de libertar os territórios dos imperativos da lógica da racionalidade economicista, suscitando uma humanidade verdadeiramente humana, convivendo pacificamente com a alteridade.

No âmbito da busca de articulação social, nas diversas escalas do mundo, mesmo diante das adversidades a mudanças efetivas, ressurgem ações alternativas de vida tal como a do socialismo participativo que se fundamenta no diálogo entre as classes sociais, primando pela garantia do direito de todos e todas à vida na Terra. O que, por outro lado, deve ser pensado de acordo com as vicissitudes do processo histórico.

Ao abordar a epidemia, os socialistas devem encontrar todas as ocasiões para lembrar aos outros a urgência da solidariedade internacional. Concretamente, precisamos agitar nossos amigos progressistas e seus ídolos políticos para exigir um aumento maciço da produção de kits de teste, suprimentos de proteção e medicamentos salva-vidas para distribuição gratuita aos países pobres. Cabe a nós assegurar que a garantia de cuidados de saúde universais e de alta qualidade se torne uma política tanto externa como interna. (Davis, 2020, p. 9)

Urge, portanto, a realização de investimentos em ações viabilizadoras de serviços públicos sociais como em saúde e educação, combatendo o referido "consumismo instantâneo". De acordo com Ribeiro (2020, p. 168), "Somente o Estado é capaz de articular os recursos para os investimentos necessários à organização da saúde pública, tendo como princípio o acesso universal da população"3, o que se coloca para processos, também, de longo prazo no âmbito do uso do território, envolvendo, dialogicamente, as diversas instituições progressistas da sociedade.

A Universidade Pública, dentre outras instituições sociais, não pode eximir-se do seu papel fundamental no que tange ao desenvolvimento de processos de diálogos sobre a condição humana no mundo, através da realização de atividades de assessoria não "para", mas "junto com" a coletividade social da qual faz parte. Sem o que não se conseguirá nunca retomar os rumos, já trilhados algumas vezes, no sentido da concretização dos interesses das classes subalternizadas na busca de serem mais cidadãos/ãs em contexto de formação

\footnotetext{
${ }^{3}$ Contra o discurso da ausência de recursos financeiros, Piketty (2019) defende a necessidade de taxar o patrimônio privado das classes dominantes.
} 
socioeconômica e territorial que sempre lhes negou direitos mínimos à existência. Entretanto, para o cumprimento de tal papel, cabe a superação de diversos obstáculos.

Desse modo, um grave obstáculo a que se instale um processo de reflexão consequente é o contraste crescente, na Universidade, entre os seus grandes momentos e esse cotidiano tornado miserável pela ameaça já em marcha de uma gestão técnica e racionalizadora, que leva ao assassinato da criatividade e da originalidade. Em nome do cientismo, comportamentos pragmáticos e raciocínios técnicos, que atropelam os esforços de entendimento abrangente da realidade, são impostos e premiados. Numa universidade de resultados, é assim escarmentada a vontade de ser um intelectual genuíno, empurrando-se mesmo os melhores espíritos para a pesquisa espasmódica, estatisticamente rentável. Essa tendência induzida tem efeitos caricatos, como a produção burocrática dessa ridícula espécie de pesquiseiros, fortes pelas verbas que manipulam, prestigiosos pelas relações que entretêm com o uso dessas verbas, $\mathrm{e}$ que ocupam assim a frente da cena, enquanto o saber verdadeiro praticamente não encontram canais de expressão. (Santos, 1992, p. 103-104)

Após a superação de tais obstáculos inerentes à sua própria escala interna, destarte, cabe à Universidade, junto com seu povo, deslindar a lógica das ações contemporâneas de uso do território, fomentando a imaginação de outros usos, resgatando e valorizando as vozes diversas dos lugares que, pela própria dinâmica contraditória da história, ainda não foram cooptadas de todo pela racionalidade hegemônica de cunho economicista.

A parceria Universidade-Povo, decerto, aproveitar-se-á das condições existenciais a fim de vislumbrar alternativas capazes de nortear ações criativas e inovadoras, visando preparar a coletividade territorial para, mobilizando os seus valores solidários, auxiliar na luta pela concretização do direito ao entorno. Com isso, seus lugares fortalecer-se-ão para o enfrentamento da presente e de outras crises sanitárias de caráter pandêmico que possivelmente poderão acontecer posteriormente à atual.

\section{CONCLUSÃO}

A análise das relações dialéticas estabelecidas entre o espaço urbano como território usado e o fenômeno da pandemia suscitando ações socialmente consequentes, no contexto de uma sociedade de classes altamente desigual e injusta, demonstrou que os impactos catastróficos do referido fenômeno acham-se intrinsecamente relacionados com a natureza das ações que usam o território como recurso.

Consequentemente, para superar os impactos considerados (situação de maior vulnerabilidade dos homens e das mulheres pertencentes às classes subalternizadas residentes em CIS/ZEIS e necessidade se superar o medo de sair de casa a fim de obter alguma renda para sustentar suas respectivas famílias dentre outros), faz-se necessário reverter 0 atual sistema de ações fundamentado na lógica de uso puramente capitalista no ser e pensar o território, eliminando as seculares desigualdades e injustiças socioterritoriais refletidas pelas paisagens dos centros urbanos. 
A opção pelo materialismo histórico-dialético como método de abordagem - auxiliado pelos métodos de procedimentos relativos à retomada de ideias sobre o tema ora proposto, à escuta das pessoas que mais sofrem com o atual processo de uso do território e ao uso de imagens representativas da problemática - foi bastante apropriada para a concretização do objetivo deste ensaio.

A principal contribuição científica da reflexão ora realizada reside no fato de recolocar a relevância do entendimento do mundo como uma totalidade complexa que está em permanente movimento em algum sentido, continuando a abrir novas possibilidades em termos da realização de pesquisas e ações capazes de, junto com as classes sociais subalternizadas, imaginar e buscar possibilidades para implementar formas justas de uso do território que concretizem efetivamente a condição da cidadania para todas as classes sociais que se acham presentes no território.

Nesse sentido, utilizou-se do território usado como categoria de análise da discussão influindo no acontecer da COVID-19, como fenômeno inerente à quebra do metabolismo sociedade-natureza, de acordo com as especificidades territoriais em Recife. Compreendeu-se que as especificidades deste lugar são resultantes das diferenças referentes às desigualdades e injustiças sociais herdadas constituindo rugosidades inerentes ao processo de formação histórico-geográfica do Brasil, o que se buscou demonstrar pelos mapas e conteúdo das entrevistas realizadas.

Contudo, insiste-se na necessidade de se investir na implementação de ações socialmente consequentes - ampliando as redes dos serviços de saneamento, atenção à saúde e transportes públicos sociais, associados a formas justas e dignas de habitação para a coletividade - a fim de que se consiga fortalecer os espaços opacos no sentido de reagir eficazmente contra os efeitos perversos de qualquer pandemia que venha a acontecer na cidade.

\section{REFERÊNCIAS}

Barbosa, J. L. \& Teixeira, L. (2020). Territórios populares entre as desigualdades profundas e 0 direito à vida. In: Carlos, A. F. A. (Org.) São Paulo, FFLCH/USP, p. 67-77.

Bihr, A. (2020). França: pela socialização do aparato de saúde. In: Davis, M. (Org.) Coronavírus e a luta de classes. Brasil: Terra sem amos, p. 25-30.

Bitoun, J. (1996). Análise dos bairros do Recife através da distribuição da renda. Revista de geografia, Edição especial, p. 41-55.
Bnb. (2019). Informações socioeconômicas municipais para Recife, Pernambuco. Disponível: http://www.bnb.gov.br

Carvalho, R. A. 2020. Doenças infecciosas emergentes na fronteira do desmatamento. In: Young, C. E. F. \& Mathias, J. F. C. M. (Org.), Covid-19, meio ambiente e políticas públicas. São Pauo, Hucitec, p. 92-100.

Castilho, C. J. M. de. (2015). Por uma geografia social dos serviços: articulando pedaços de uma realidade fragmentada para explicar a natureza das interrelações espaço-serviços. In: Castilho, C. J. M. de. (Org.), Movimentos sociais, academia e sociedade. Por um espaço do cidadão. Recife: Edufpe, p. 155-292. 
Castilho, C. J. M. de. (2019). O uso neoliberal do espaço - impactos sobre os "territórios da vida humana" na cidade. Revista Okara: Geografia em Debate, 13(2), 597-623, 2019.

Castilho, C. J. M. de. (2020). Territórios violados, resistências e massacres de povos e pobres na história do Brasil - mas a luta continua. Boletim Goiano de Geografia, (40), p. 1-25, doi.org/10.5216/BGG.v.40.60739

Castilho, C. J. M. de, Pontes, B. A. N. M., \& Brandão, R. J. A. (2018). A destruição da natureza em ambientes rurais e urbanos no Brasil: uma tragédia que ainda pode ser revista. Ciência e Natura, Santa Maria, (40), p. 16-20, doi.org/10.5902/2179460X30407

Castro, J. de. (1954) A cidade do Recife. Ensaio de geografia urbana. Rio de Janeiro: Casa do Estudante do Brasil.

Davis, M. (2020). A crise do coronavírus é um monstro alimentado pelo capitalismo. In: Davis, M. (Org.) Coronavírus e a luta de classes. Brasil: Terra sem amos, p. 05-12.

Guimarães, E. S. (2020). As pandemias e as populações invisíveis: do Brasil do século XIX ao Brasil do Covid-19. In: Almico, R. de C. da S., Goodwin Jr., J. W., Saraiva, L. F. (Org.) Na saúde e na doença: história, crises e epidemias: reflexões da história econômica na época da covid-19. São Paulo: Hucitec, p. 98-106.

Fórum Nacional de Entidades Metropolitanas-Fnem. 2019. Região Metropolitana do Recife (PE). Disponível: http://www.fnembrasil.org

Freyre, G. (1981). Sobrados e mucambos. Rio de Janeiro: José Olympio.

Ludermir, R. e Coelho, R. (2016-2018). Terra e moradia. Conflitos fundiários urbanos em Pernambuco. Recife: Habitat para a humanidade.

Harvey, D. (2004). The new imperialism: accumulation by dispossession. Socialista Register, v. 40, The new imperial challenge, p. 63-87.

Harvey, D. (2013). Os limites do capital. São Paulo: Boitempo.

Harvey, D. (2020). Política anticapitalista em tempos de COVID-19. In: Davis, M. (Org.) Coronavírus e a luta de classes. Brasil: Terra sem amos, p. 13-23.
Krenak, A. (2020). O amanhã não está à venda. São Paulo: Companhia das Letras.

Lab Moradia no Centro. (2018). Recife: Habitat para a humanidade/lbdu/Cities

Alliance/Fase/Interação/Cpdh/Mtst/Caus/Solid ground/ Uhph.

Lacoste, Y. (2019). A geografia - isso serve, em primeiro lugar, para fazer a guerra. Campinas: Papirus.

Lefebvre, Henri. (1974). La production de l'espace. Paris: Éditions Anthropos.

Melo, M. A. B. C. (1985). A cidade dos mocambos: Estado, habitação e luta de classes no Recife (19201960). Espaço e Debates, 14, p. 45-66.

Melo, M. L. de. (1978). Metropolização e subdesenvolvimento. $O$ caso do Recife. Recife: Editora da Universidade Federal de Pernambuco.

Meneses, J. N. C. (2020). "Águas passadas [...] movem moinhos": água, abastecimento, higiene e processo saúde-doença na modernidade. In: Almico, R. de C. da S., Goodwin Jr., J. W., Saraiva, L. F. (Org.) Na saúde e na doença: história, crises e epidemias: reflexões da história econômica na época da covid-19. São Paulo: Hucitec, p. 48-58.

Nascimento, M. M. P. do, Castilho, C. J. M. de. (2018). Habitação de interesse social: intencionalidades na realocação de moradias e reuso do solo no ambiente urbano. Revista Brasileira de Geografia Física, 11, p. 560-584.

Piketty, T. (2019). Capital et idéologie. Paris: Éditions du Seuil.

Ribeiro, D. (2015). O povo brasileiro: a formação e 0 sentido do Brasil. São Paulo: Global.

Sá, M. de F P. de. (2020). A ecologia da doença. 082 Notícias. Disponível:

https://082noticias.com/2020/02/11/maria-de-fatima/

Santos, M. (1987). O espaço do cidadão. São Paulo: Nobel.

Santos, M. (1992). 1992: a redescoberta da natureza. Estudos Avançados, 6(14), p. 95-106.

Santos, M. (1997). A natureza do espaço. Técnica e tempo, razão e emoção. $2^{\mathrm{a}}$ ed. São Paulo: Hucitec.

Santos, M. (2000). Por uma outra globalização. Do pensamento único à consciência universal. Rio de Janeiro: Record. 
Santos, M. et al. O papel ativo da geografia. Um manifesto. Florianópolis: XII Encontro Nacional de Geógrafos, 2000.

Santos, M., \& Silveira, M. L. (2001). O Brasil. Território e sociedade no início do século XXI. Rio de Janeiro: Record.

Ujvari, Stefan Cunha. (2012). A história da humanidade contada pelos vírus. Bactérias, parasitas e outros microorganismos... São Paulo: Editora Contexto.

Young, C. E. F. (2020). Covid-19 e cobiça: a importância da vida humana para a elite brasileira, ontem e hoje. In: Young, C. E. F. \& Mathias, J. F. C. M. (Org.), Covid-19, meio ambiente e políticas públicas.

São Paulo, Hucitec, p. 144-149. 